\title{
¿PRÁCTICA DE PALABRAS O DE IDEAS? PANORAMA HISTÓRICO DE LA ENSEÑANZA DEL LÉXICO EN COSTA RICA
}

\author{
Marta Rojas Porras \\ Docente de la Universidad de Costa Rica. \\ Óscar Aguilar Sandí \\ Coordinador del Consejo Editor de la revista Umbral \\ (Colegio de Licenciados y Profesores en Letras, Filosofía, Ciencias y Artes). \\ Recibido 30-VIII-2005 \\ - Aceptado 08-XI-2005
}

\begin{abstract}
Resumen: Se sigue el rastro del tratamiento didáctico del léxico en Costa Rica desde inicios del siglo XX con la figura de Carlos Gagini, se revaloran obras como las de Elizondo y Cascante, hasta el trabajo de Sánchez Corrales. El recorrido muestra concepciones formalistas y metalingüísticas, comunicativas, de las funciones sociales $y$, por último, enfoques procesuales (pragmáticos y sociolingüisticos).
\end{abstract}

Palabras clave: Léxico, lingüistica aplicada, didáctica, libro escolar, lengua materna

\begin{abstract}
The didactical treatment of lexicon in Costa Rica from the beginning of the XXth century is traced through the with Carlos Gagini. Works by Elizondo and Cascante are also evaluated as well as works by Sánchez Corrales. The study shows formalist-metalinguistic, communicational and social function-oriented conceptions. Lastly, it offers a pragmatic and socio-linguistic focus.
\end{abstract}

Key words: Lexicon, applied linguistics, didactics, textbooks, first language.
El propósito de este artículo es mostrar, en términos generales, las concepciones y prácticas que, en Costa Rica, han orientado el tratamiento didáctico recibido por el componente léxico en la enseñanza de la lengua. Los datos que se presentan se derivan de una búsqueda bibliográfica y corresponden a parte del estudio que sustenta la propuesta metodológica para el desarrollo de la madurez léxica en la población de la escuela costarricense, llevada a cabo desde el INIE.

\section{El siglo XIX: los catones y el predominio de lo moral y europeo}

En el siglo XIX se enseñó la lengua materna con El Catón y La Cartilla. Esta situación era general al mundo occidental. En aquella época, efectivamente, los dos textos más utilizados para el aprendizaje de la lectura fueron las cartillas y los catones, aunque no los únicos.

Según el Diccionario de la Real Academia Española, Cartilla es un "cuaderno pequeño, impreso, que contiene las letras del alfabeto y los primeros rudimentos para aprender a leer". Este fue el primer libro escolar por excelencia en la historia 
de Occidente. Catón es el "libro compuesto de frases y periodos cortos y graduados para ejercitar en la lectura a los principiantes". Era, por lo tanto, el segundo libro de lectura después de la cartilla, pues ésta se limitaba principalmente a la presentación de las letras (UNED de España, 2004).

Su origen data de la obra del moralista y gramático latino del s. III d.C. Dionisio Catón, autor de Los Disticha Catonis o "Dichos de Catón". Constituían un breve tratado de urbanidad y moral, recopilación de sentencias morales con 174 máximas en verso, precedidas por 56 preceptos en prosa. De todos los libros de moral que se emplearon en la Edad Media para la educación de la juventud y la ejercitación en la lectura, ninguno adquirió tanta fama como éste, hasta el punto de que, por extensión o sinécdoque (nombrar la obra por su autor) se acabó llamando "catón" a todo libro con el que se aprendía a leer (UNED de España, 2004; García González, 2004).

Fue, sin duda, el Catón el libro escolar más antiguo para la lectura "de corrido" -y a la vez moralizadora- y el de mayor difusión en los países de la Europa occidental y sus colonias.

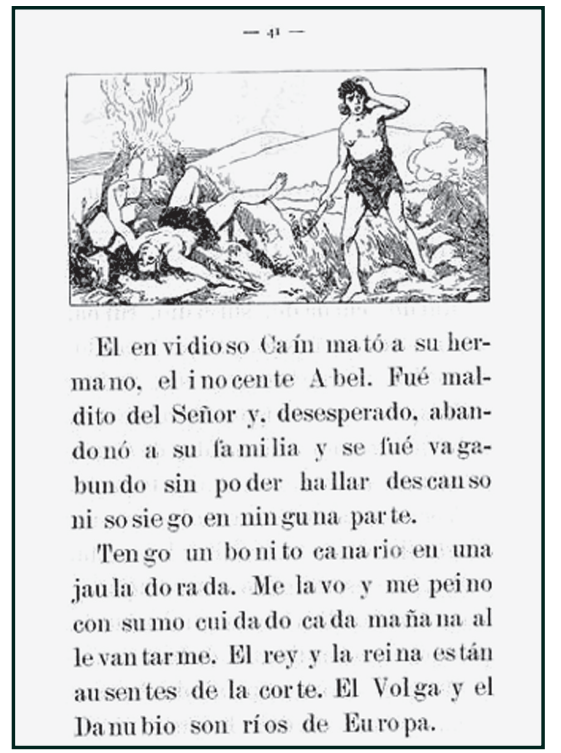

Merecen citarse las ediciones de la obra de Catón en los siglos XVIII y XIX de la casa Orga (Valencia), y Sierra y Martí, de Barcelona -probablemente estas fueron las que circularon en Costa Rica, pues desde finales del siglo XVIII el Catón se extendió en Hispanoamérica, especialmente en Argentina, donde logró una gran difusión el llamado Catón Cristiano (García González, 2004)-. La difusión e influencia del Catón parecen haber sido consecuencia de su disposición y estilo didáctico, así como de su sencillez y graduación.

Una vez dominado el catón se pasaba a los propiamente llamados libros de lectu$r a$, que se pueden dividir en dos grandes grupos: 1- El conjunto de obras consideradas texto escolar y que constituyen realmente el tercer libro de lectura, y 2- el conjunto de diversos libros de lectura sin una finalidad específica para el aprendizaje de la misma (catecismos, libros históricos o constitucionales, antologías literarias, colecciones de fábulas, libros de urbanidad, obras de geografía e historia, devocionarios, libros de cosas, biografías...) (UNED de España, 2004).

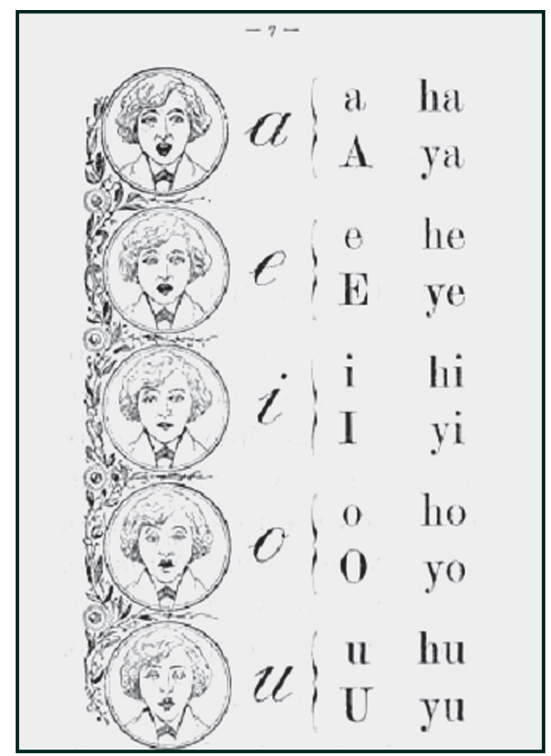


Muy resumidamente podemos decir que el Catón era un libro con lecturas elementales -muchas de las cuales tenían un contenido moralizador- que contenían frases y períodos cortos para enseñar y ejercitar en la lectura a los principiantes.

\section{Inicios del siglo XX: Orientación hacia el conocimiento formal de la lengua en detrimento de las habilidades comprensivas del estudiantado}

Los textos de la tradición europea (Catón y otros posteriores) irradiaron su legado en nuestro país durante el siglo XX, como tangencialmente se mostrará en las líneas que siguen.

\section{Carlos Gagini Chavarría: precursor de la enseñanza del léxico como objeto específico}

A diferencia de lo que generalmente ocurre en la época, el maestro Carlos Gagini aborda el léxico como objeto específico en la clase de lengua materna, atendiendo nociones semánticas o lógicas de las palabras.

En Vocabulario de las escuelas (1897) advierte que este es "un libro en que se hallen las palabras usuales, clasificadas según su significación ó sus relaciones lógicas" (p. II). Ahora bien, ¿qué entendía el autor por "palabras usuales"? ¿"Usuales" dónde? No son de recurso cotidiano -y es dudoso que lo fueran en esa época, al menos entre la niñez costarricense- términos que denotan vegetales como "berza", "chirivía", "acelga" o "acedera"; tipos de repostería como "alcorza"; licores como "malvasía"; y accesorios de la vestimenta tales como "zagalejo", "ajorca", "cañutillo", "arrequives" o "airón". Gagini está consciente de esta dificultad operativa, pues a determinados términos (quizás no los suficientes) tuvo que adosarles la correspondiente definición; por ejemplo:

"mosto m. (zumo de la uva antes de hacerse vino)" (p. 144)

"rosoli m. (especie de mistela)" "ratafía f. (rosoli de guindas y otros ingredientes)" "hipocrás m. (vino con azúcar, canela, etc.)” (p. 145)

"basquiña f. (saya negra)" (p. 158)

"cairel m. (fleco que adorna algunas ropas)" (p. 159)

En torno a esto, en las "Advertencias" señala Gagini que: "Solamente las voces poco comunes y las que pueden ofrecer dudas van acompañadas de definiciones ó notas explicativas; para las demás debe el maestro valerse de sus propios conocimientos o de los diccionarios".

Sin embargo, si bien no se aclara con base en qué criterios el autor decidió cuáles voces eran poco comunes o capaces de generar duda, es probable que el término "usual" refiera a la norma peninsular, enseñada en esa época como el deber ser del uso culto en las excolonias latinoamericanas.

Con respecto a la parte XXVIII del libro, "Nombres de pila", además de incluir nombres que conservan su vitalidad en nuestros días, hace figurar otros como "Calasancio", "Ceferino", "Celidonio", "Clodoveo", "Emerenciana”, "Eufrasio", "Indalecio", "Pascasio" y "Sulpicio", que ya entonces debían encontrarse en progresiva obsolescencia.

Coincidente con las ideas de la época, se observa en este trabajo la carencia de una noción de variante dialectal; pues para la oficialidad escolar -tanto como para el ciudadano de la calle- la variante literaria peninsular constituía "la lengua" por excelencia. En virtud de este paradigma, a los vocablos que se apartaran de la norma española peninsular se les estigmatizaba como "vulgarismos":

\footnotetext{
"patata f. vulg. papa" "pimiento m. vulg. chile"(p. 21) "biscocho m. vulg. galletilla" "sorbete $\mathrm{m}$. vulg. helados" (p. 144)

"zarcillo $\mathrm{m}$. -

pendiente m. vulg. — arete" (p. 159)
} 
Hay una notable excepción, en la que más parece estarse haciendo una observación dialectológica que destacando una "corruptela":

*refresco m. (En Costa Rica fresco)" (p. 145)

De hecho, algunas de las definiciones que Gagini proporciona iban dirigidas a desterrar tales "barbarismos" del habla costarricense:

"galleta f. (pan sin levadura, para ejércitos y buques)" (p. 144)

"enaguas f. pl. (vestido interior de las mujeres) falda $\mathrm{f}$.

saya f. $\longrightarrow$ Prenda exterior" (p. 158)

"brazalete $\mathrm{m}$. (Se pone casi siempre cerca del hombro)

pulsera $\mathrm{f}$.

manilla f. $\longrightarrow$ Se pone en la muñeca.” (p. 159)

En El lector costarricense (1902), serie de cuatro volúmenes, Gagini ofrece una colección destinada a usarse en las clases de lectura de las escuelas primarias. Esta obra constituye una antología de textos breves y heterogéneos, la mayoría con evidente intención moralizante, profusamente ilustrados con fotografías y dibujos. Incluye desde poemas y extractos de ciertas obras literarias hasta semblanzas históricas y descripciones geográficas.

Por ejemplo, el libro cuarto consta de 61 lecturas. Algunos de los títulos: "Aseo corporal", "Armas y pabellón de Costa Rica", "La erupción del Irazú", "Lincoln" y "El Dr. José Ma. de Castro", sin indicación de su autor. Otros títulos que aparecen: "San José I", "San José II", "Don Braulio Carrillo" (de Máximo Soto Hall), "El alcoholismo" (Enrique Jiménez), "Origen de la ciudad de San José” (J.B. Calvo), "La paz” (poesía de Rafael Ginard de la Rosa), "El Niágara", "El Vesubio" (P.A. de Alarcón), "Los aborígenes de Centro América" (Agustín Gómez Carrillo) la cual se limita a comentar aspectos del Popol Vuh, "David Livingstone" (Celso Gomis), "La Biblia" (Donoso Cortés), "La limosna" (poema de Ventura Ruiz Aguilera, español), "El cuento del rebuzno"
(Miguel de Cervantes), "La conciencia" (poema de Víctor Hugo), etc.

No obstante que los 4 libros carecen de un prólogo o nota preliminar que proporcionara instrucciones sobre su finalidad, se deduce que estaban pensados -aparte de los propósitos moralizantes que evidencia el contenido de los textos- para incrementar o enriquecer el vocabulario del alumnado. Se deduce esto por cuanto la itálica, empleada en forma aparentemente arbitraria, parece haber estado señalando vocablos clave, que se pretendía que los docentes trataran o definieran en clase, para su adquisición por parte de los niños. Así, por ejemplo, la lectura $32^{\mathrm{a}}$ "La noche del 11 de octubre de 1492" (p. 93), resalta los siguientes vocablos: popa, alucinación, gentilhombre, confidentes, emersión, brazas, derrota, amainaron, bruma, anfiteatro.

En El vocabulario de los niños (1904), lo primero que Gagini deja claro desde la introducción "A los maestros" es que esta obra "es una mera adaptación del método del profesor francés Boisseau" (p. I). Si bien en nuestra época causa extrañeza semejante confesión de no originalidad, por aquellos días ser fiel imitador de un francés constituía el mayor mérito. Este trabajo “...se propone suministrar gradualmente a los niños el caudal de voces que necesitan para nombrar los objetos que van conociendo y para expresar con propiedad sus juicios." (id.) Su ruptura en términos pedagógicos con lo acostumbrado hasta entonces queda expresa en estas palabras:

Bien aplicado este método, hace innecesarios los textos de gramática y conduce sin violencia al conocimiento del idioma patrio (...). Todos los ejercicios han de ser intuitivos siempre que sea posible y deben ir precedidos de una conversación entre el maestro y los discípulos (...). (id.) Es indispensable despertar la atención e interés de los alumnos, haciendo que observen y juzguen por sí mismos... (p. II)

Aunque la enseñanza de la lengua a partir de procesos inductivos y no de metalenguajes es un verdadero avance, la 
ausencia de consideraciones sociolingüísticas, condición propia de la época, también es palpable:

Ocurrirá a menudo que en una localidad recibe un objeto un nombre diferente del que lleva en el texto: en tal caso, debe el maestro hacer que los escolares prefieran el del libro y considerarse el otro como impropio. Solo así podrá lograrse la unificación del idioma y podrán desterrarse los vicios de lenguaje que desfiguran la lengua castellana en las repúblicas de Hispano América. (id.)

El primer volumen, denominado Curso elemental, se destinaba a los grados $2^{\circ}$ y $3^{\circ}$ de las escuelas primarias. Estaba subdividido en lecciones. La mayor parte de estas lecciones inicia presentando una ilustración o conjunto de ilustraciones etiquetadas con el vocablo descriptor; así por ejemplo, la lección 1 a "Los sentidos" muestra "ojo = vista", y señala "pestaña" y "párpado"; "oreja = oído", "nariz = olfato", "boca = gusto" y señala "labios"; "mano = tacto" (p. 1). La lección $2^{\mathrm{a}}$ "Los colores" muestra un cuadrado relleno de "blanco", uno "negro", "rojo", "azul", "amarillo" y "verde" (p. 2). La lección 4 "Las aves" muestra un "huevo", un "gallo" y señala el "pico" y la "cresta", un "pavo" y señala el "moco", así como un "loro" (p. 3). La lección 95 "Enfermedades" no incluye ilustración, sino que enlista seis palabras y las acompaña de términos clave para su definición, así:

$\begin{array}{ll}\text { "Fiebre } & \text { Temperatura alta } \\ \text { Tisis } & \text { Pulmones } \\ \text { Ictericia } & \text { Color amarillo } \\ \text { Difteria } & \text { Garganta, asfixia } \\ \text { Neuralgia } & \text { Dolor, cabeza } \\ \text { Viruela } & \text { Erupción, pústulas"(p. 95) }\end{array}$

Análogamente, la lección $96^{\text {a } ~ " M e d i-~}$ camentos" incluye los siguientes conceptos (que hoy constituyen una curiosidad histórica):

$\begin{array}{ll}\text { "Quinina } & \text { Píldoras, fiebre } \\ \text { Ipecacuana } & \text { Vómito, jarabe } \\ \text { Mostaza } & \text { Sinapismo } \\ \text { Aceite de castor } & \text { Cápsulas } \\ \text { Ruibarbo } & \text { Purgante, polvo } \\ \text { Borraja } & \text { Infusión, sudorífico } \\ \text { Tolú } & \text { Pastillas, tos } \\ \text { Fricciones } & \text { Alcohol, vinagre" (p. 96) }\end{array}$

Como se observa, la temática abordada en cada una de las "lecciones" muestra una organización en campos conceptuales.

Otro enfoque que, al contraponer las prácticas educativas del momento con las del presente, permite valorar el cambio de mentalidad y el aporte de los estudios de la educación especial -por lo que para la sensibilidad actual resulta decididamente inapropiado- es el de la lección 94a , titulada "Defectos físicos". En este rubro Gagini incluye: "Cojo.-Manco. -Tuerto. -Jorobado. Sordo. -Mudo. -Tartamudo. -Tullido. -Bizco. -Ciego. Patizambo. -Desdentado" (p. 94)

En relación con las tareas para apropiarse del conocimiento, los ejercicios que propone consisten exclusivamente en dos tipos:

Completar espacios en blanco (En la lección 28 "El tigre", dice: "El........es un animal..... Vive en los....... Es de color.........con ........ negras" [p.21]. Y en

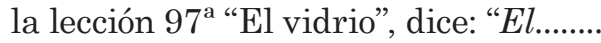
se hace con arena, potasa, cal y otras sustancias minerales. El vidrio es muy útil porque........" [p. 97]).

Composición escrita o "formar frases" empleando las palabras de la lección.

Únicamente se contempla un ejercicio por lección, de manera que ambos tipos nunca coexisten.

En cuanto al Curso superior, para los grados $4^{\circ}, 5^{\circ}$ y $6^{\circ}$, "es más gramatical que el Elemental", según el autor, pues ya alberga entre sus contenidos "Sufijos, Prefijos, Familias de palabras, Parónimos, Homónimos, Sinónimos, Antónimos, Lenguaje figurado, Simbolos, Perifrasis, Modismos, Refranes, Origen de las palabras, Frases latinas" (p. I).

En consecuencia, los ejercicios aumentan en diversidad y complejidad. Como composición escrita se pide hacer descripciones ("Describir una mesa ya preparada..." [p. 17], "Describir el dormitorio" [p. 21]), formar derivados, explicar sus significados o reemplazar con ellos a un infinitivo, etcétera. 
Los contenidos del libro se concibieron con una orientación en la que los usos lingüísticos de los estratos medios altos y europeizados son considerados como la norma. Hay indicios de ello a lo largo y ancho de los dos volúmenes. Por ejemplo, la lección $101^{a}$, "Las aberturas", exhibe el dibujo de una casa de dos pisos, con amplios balcones, en medio de una propiedad arbolada. Las basas provistas de respiraderos y escotillón. En el techo, elegantes tragaluces, buharda, gateras y chimenea. En una parte del muro de atrás, se abre la "puerta cochera" (p. 92). En consonancia con esto, hay constantes referencias al carnero, que es una especie inusitada en estas latitudes.

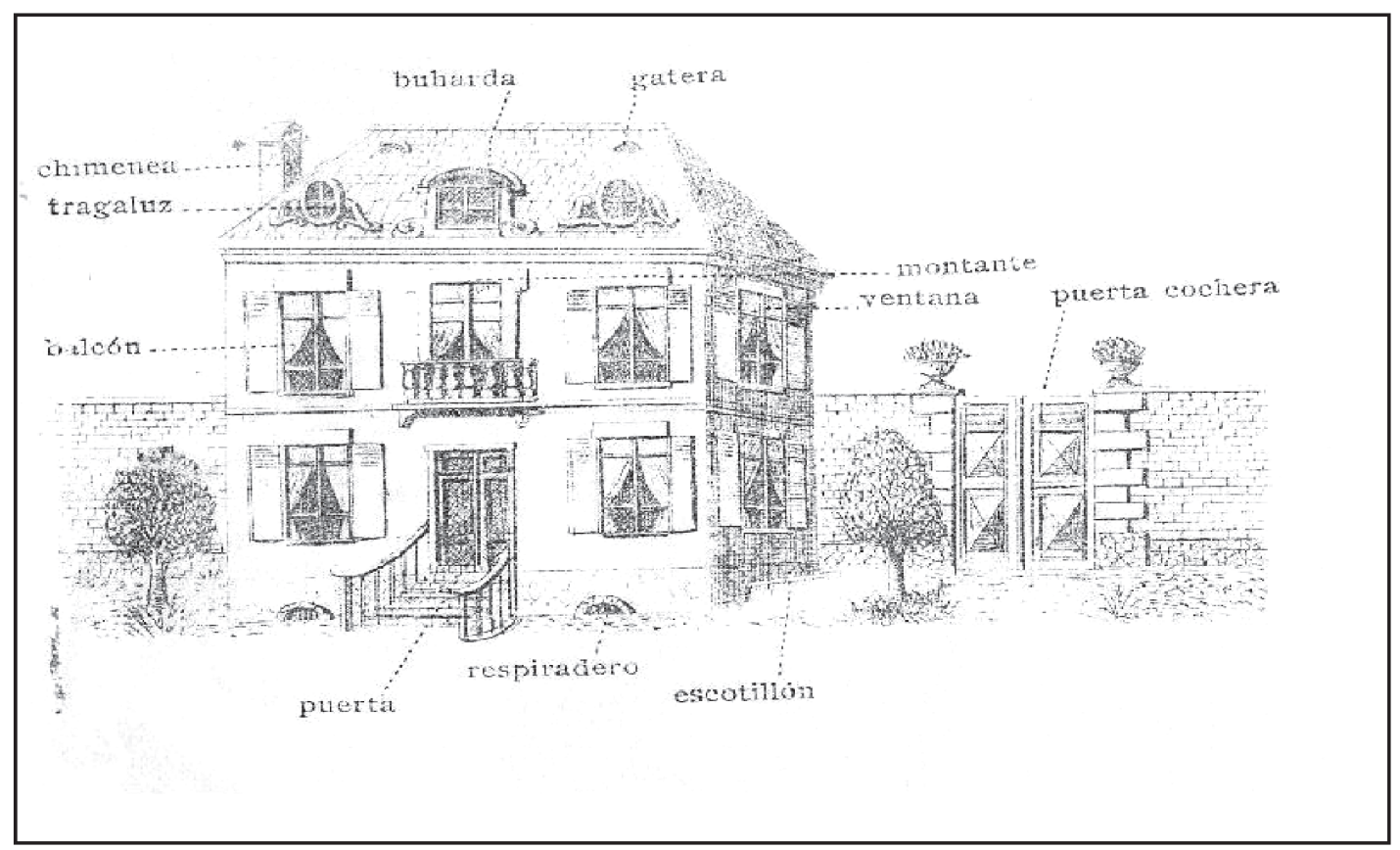

Gagini, C. El vocabulario de los niños. P. 92.

Otro aspecto que se detecta en $E l$ vocabulario de los niños es la pudibundez o puritanismo a la hora de referirse al cuerpo humano. Específicamente la lección $114^{\mathrm{a}}$ "La anatomía humana" (p. 103) se ilustra con la figura desnuda de un hombre (haber mostrado a una mujer en esa situación se habría considerado quizás pornográfico), desde una perspectiva casi de perfil, con la pierna derecha flexionada hacia delante como dando un paso; de modo que ocultaba de la vista los órganos genitales. Desde luego, no se hace la más mínima alusión a estos ni a sus funciones fisiológicas; simplemente debía de ser inconcebible en una escuela.

Si bien el estudio que se analiza a continuación no es estrictamente sobre el léxico y su enseñanza, pues su objetivo es de índole ortográfica, interesa destacar la propuesta de selección de palabras, con la correspondiente dosificación por grado, todo ello sobre la base de la producción textual del niño y del juicio de expertos. 


\section{Lilia González y Manuel Clemente Quesada: definición de un léxico meta para ortografía a partir de la producción del estudiantado}

Casi tres décadas después de la obra del precursor, Lilia González y Manuel Clemente Quesada, en Selección de palabras para ortografia (1930) proponen un trabajo concebido para aplicarlo en el circuito de San José; pero posteriormente la Secretaría de Educación Pública decidió editarlo para uso de todas las escuelas del país. Esta selección proporciona una lista de 1500 voces, ordenadas alfabéticamente, que los alumnos deben ir dominando ortográficamente conforme avanzan en grados. El tratamiento que se esperaba para la lista era que el docente escribiera de una en una las palabras -ya fuera en la pizarra o en carteles-, las pronunciara, las ubicara en frases y explicara su estructura, su etimología y las reglas a que obedece su ortografía; que los alumnos las transcribieran en sus libretas, las leyeran con atención, las dividieran en sílabas, las dividieran en letras y también en sus elementos morfológicos, las contextualizaran en frases, las memorizaran, y así por el estilo.

La inquietud por realizar este proyecto nace porque "No habia una norma única y fundamentada para determinar qué palabras deben integrar la lista, ni en qué número" (p. 3, el resaltado es del original). Así exponen los autores la metodología que se siguió para levantar la lista (p. 4):

$1^{\circ}$ - Todos los maestros de esta ciudad estudiaron cuidadosamente los distintos trabajos escritos de los alumnos, y cada uno formó una lista de las palabras allí empleadas, señalando con un exponente la frecuencia con que fue empleada cada una.

$2^{\circ}$ - Una comisión de directores, por cada grado, resumió en una las respectivas nóminas de grado.

$3^{\circ}$ - Nosotros fundimos en una las seis listas recibidas y sacamos luego los vocablos de mayor exponente, los cuales distribuimos por grados según su uso y su mayor o menor dificultad ortográfica.
La indicación es que "el número de vocablos que debe dominar absolutamente cada grado queda así: I grado, 100; II grado, 300; III grado, 600; IV grado, 900; V grado, 1200; VI grado, 1500" (p. 4-5, el resaltado es del original). Según comentan, este límite está "aconsejado por la experiencia de algunos" (p. 5).

Dada la naturaleza de la recopilación del corpus, y su finalidad ortográfica, no se aplicó en absoluto la noción de lexema o paradigma, sino que en el caso de los verbos se incluyeron las formas tal y como se les encontró flexionadas en los textos: "almorcé", "llevaba", "cayó", "reduzco", "envía", "eran", "oye", "habrá", "hemos", "leyendo", "vayamos", "disuelve", "nazca" у similares.

Por otra parte, los autores están muy conscientes de la utilidad práctica del componente motivacional en las clases, para lo cual proponen actividades que favorecen la participación competitiva del tipo "torneos" o "concursos". Así lo argumentan:

Como en todo otro ramo de la enseñanza, es indispensable desarrollar y mantener el interés de los niños por el estudio de la ortografía. Y como no podemos esperar que los educandos comprendan, desde los grados inferiores, la importancia de la escritura correcta y sientan el deseo de adquirirla, se hace necesario mantener esa preocupación por medio de concursos, que ponen en gran actividad al alumno por el interés inmediato del triunfo (p. 7).

Estos dos autores son de los primeros costarricenses que ofrecen indicios de una perspectiva sociolingüística en un trabajo de índole didáctica, cuando expresan en las "Observaciones finales":

...como es sabido que el vocabulario usual varía con las diferentes regiones y localidades, usos, costumbres y ocupaciones peculiares, es en este punto también donde el cuidado inteligente de los maestros podrá acopiar observaciones importantes que luego habrán de aprovecharse, de acuerdo con los superiores, para formular, de manera definitiva, las listas regionales (p. 17).

Otro acierto que se observa en el repertorio meta propuesto por estos autores 
consiste en que lo definen a partir de textos producidos por los sujetos de la educación, lo cual evidencia una actitud visionaria.

\section{La década de los 40: Inicios de una discusión de los objetivos comunicativos en la enseñanza de la lengua}

\section{Hernán Zamora Elizondo: una propuesta visionaria para la enseñanza de la lengua}

Hernán Zamora Elizondo, fundamentado en estudiosos europeos de la época, como Claparede, Cousinet, Lombardo Radice y Laura Brackenbury, en Educación de la lengua materna (1942) hace propuestas tan revolucionarias que, aun al día de hoy, están lejos de considerarse seriamente en el sistema educativo nacional.

En razón de lo anterior, señalamos algunas ideas de este autor:

1- La Educación del lenguaje no es otra cosa que educación global de la mente. En estas condiciones, no es posible concebir la educación del lenguaje como actividad divorciada de la formación educativa total del ser humano:

“... por eso (...) toda actividad humana de cualquier naturaleza que sea (...) constituye un factor esencial de la particular educación del lenguaje" (p. 6). "Ni la lógica ni la gramática explican por sí solas la vida y la naturaleza del lenguaje; ni ellas solas constituyen los medios de educación del habla humana" (p. 8-9).

2- La lengua materna se adquiere haciendo cosas con ella:

... la lengua materna no se aprende mediante la enseñanza directa (...), sino que se alcanza su conocimiento indirectamente: oyéndola y practicándola. Solo adquieren un dominio del idioma aquellos que han tenido oportunidades suficientes y satisfactorias de aprenderlo por el método natural, esto es, indirecto. (p. 7).
3- $\quad$ El léxico se debe aprender en el contexto de las ideas que se expresan y no aislado. Además, en procesos de producción propia:

Pero lo más grave es que la escuela enseña palabras y no ideas; por eso en la escuela se recita un lenguaje inexpresivo, desprovisto de la emoción que es la luz que aclara el pensamiento, un lenguaje que lo fue en otros, pero que ha venido a ser osamenta tan sólo (p. 8, resaltado en el original).

4- La enseñanza de la lengua no se circunscribe únicamente a la enseñanza de la gramática; todo lo contrario, insistir en ella provoca indisposición:

Las [actividades formativas en lengua materna: redacción oral o escrita, ortografía, recitación, lectura y audición] conducen al lenguaje correcto y aun artístico, sin necesitar el auxilio de [actividades especulativas como la gramática]; son las que (...) enseñan a hablar, enseñan a leer, enseñan a escribir. Las especulativas tienden a ampliar las posibilidades artísticas y a explicar y esclarecer el fenómeno lingüístico (...), pero un error inveterado (...) que ha querido ver en la gramática la base de la educación del lenguaje, no ha permitido que en esta materia se apliquen los principios ya enunciados. (...) el hombre resuelve acertadamente su problema lingüístico: el de su expresión, si por medio de las actividades formativas ha llegado a constituir una serie de hábitos lingüísticos capaces de alcanzar este otro fin práctico: el de su expresión correcta. Sólo tratándose de hombres de cultura superior (...) es precisa la intervención de las actividades especulativas. (p. 11-12).

5- Como práctica de estímulo, el lenguaje se debe ejercer:

...De las [inhibiciones] más perniciosas, [son las] suministradas por la misma escuela, que pretende educar el lenguaje de la manera más curiosa: educar el lenguaje sin ejercerlo, que es como enseñar a andar a los niños trayéndolos en brazos de la niñera. (...) El niño necesita expresarse, (...) necesita hablar, gesticular, dibujar, modelar; pero la escuela, lejos de aprovechar esta manifestación vital, la apaga (...); el alumno oye y ve, pero no dice, no construye, no crea. Es preciso reaccionar en forma que sea la escuela un estímulo para que el niño hable, que sólo así podrá llegarse a la educación de su lenguaje (p. 20).

6- $\quad$ Se debe favorecer un ambiente escolar en el que el niño o la niña expresen sus propias ideas: 
La palabra no es sino un signo (...), tanto la palabra como la cifra son signos de ideas, y en el lenguaje, como en las operaciones matemáticas, sólo se resuelve el problema cuando la asociación entre unas y otras ideas es correcta, es decir, cuando nos conduce a la expresión de una síntesis de pensamiento que se acomoda con la realidad. De aquí resulta otro principio básico en esta empresa de la educación del lenguaje: el niño sólo debe expresar sus propias ideas (p. 21, resaltado en el original).

7- $\quad$ La educación del lenguaje debe tener en cuenta los intereses de los educandos y su medio:

Los alumnos son mudos en muchas ocasiones porque se les retiene en una situación anormal; sáqueseles de ella, permítaseles situarse dentro de su propia vida, y se les oirá hablar o se les verá expresarse en otra forma cualquiera: dibujo, modelado, gestos, juego, etc." "[El niño] puede conocer las palabras "montaña", "cordillera", "sierra", y aun algunos nombres propios, pero esas son palabras desprovistas de sentido para la mente del niño; en cambio, ese mismo sujeto, antes mudo, será un admirable conversador cuando nos describa los diferentes pasos de un juego, cuando nos hable del animal que conoce por propia experiencia, en fin, cuando trate de aquellas cosas que le interesan. (...) No puede obligarse a beber a un asno que no tiene sed -dice un juicioso proverbio. Asimismo, no se puede hacer escuchar o trabajar a un individuo y, sobre todo, a un niño, sin haber suscitado en él un interés, es decir, una necesidad de saber y de obrar.(..) (p. 22-23).

¿No hablan todos los hombres? Sí. Y ¿de qué hablan? De aquello que está dentro de sus vitales intereses (...); sin que nadie les fije un tema. Pues de igual manera deben surgir los temas de la composición escolar: de los juegos, de las asociaciones, de las asignaturas en estudio, de las relaciones sociales, de todas aquellas actividades en que el niño se mueva desplegando su propia vida. El deber del maestro no es buscar el tema; es instigar la actividad del alma del alumno para que exprese su contenido; es situarlo en un ambiente propicio a la expresión (...), y no se exija más corrección que la adecuada al desarrollo mental [del alumno] (p. 25-28).

8- La enseñanza del lenguaje debe aprovechar todas las posibilidades expresivas y no sólo la lengua, para así promover la creatividad:

Insistimos en que el educador no puede perder de vista que el lenguaje es un medio de expresión, pero no el único; también lo son el gesto, el dibujo, el modelado, el juego, la música. Precisamente el lenguaje es el más tardío de los medios de expresión, y nuestra escuela comete el pecado de aprovechar el lenguaje como único medio expresivo. (...) es deber del maestro aprovecharse de todos para provocar la actividad intelectual creadora del educando. (...) La educación del lenguaje, como forma especial de la educación del pensamiento, ha de tener como obligado antecedente el cultivo de los otros medios expresivos anteriores a la aparición del propio lenguaje (p. 28-29).

9- Se torna imperioso aprovechar la experiencia del niño y la niña como recurso para el aprendizaje inter pares:

El solo hecho de que la escuela ofrezca al alumno un grupo de oyentes parecidos a él es ya bastante para que constituya un medio propicio al desarrollo del lenguaje. Pero ¿este conjunto, esta sociedad escolar ha sido aprovechada debidamente? Dentro de ella ¿el niño o el joven han podido actuar con libertad completa para manifestarse? Apenas sí de un modo relativo. (...)¿Qué mejor ejercicio de lenguaje? (...) Sólo en este ambiente, productor constante de estímulos, puede convertirse la composición en lo que realmente debe ser: una respuesta del alumno a la pregunta que le formulan sus propias inquietudes, y sólo así surgen los temas espontáneos: la conversación y la carta, que es su sustituto; el desarrollo de asuntos de las asignaturas preferidas, la enseñanza de juegos a los compañeros, la dramatización de escenas vividas, los estatutos de organizaciones [estudiantiles], y todas aquellas actividades lingüísticas, sin limitación en el número, que se presentan en la vida diaria a todo ser humano (p. 34-37).

Llama la atención, mutatis mutandi, el parecido del discurso de este pedagogo con valores del constructivismo y de la pragmática, en donde se sostiene la necesidad de aprender haciendo y en contextos discursivos y sociolíngüísticos particulares para desarrollar plenamente las competencias comunicativas.

\section{Roberto Brenes Mesén: Urgencia de supeditar las palabras al servicio de la comunicación}

Unos años más tarde, el profesor Roberto Brenes Mesén, quien a la sazón 
ejercía en la Northwestern University, prologa la obra Castellano, de Claudia Cascante de Rojas (1946). El benemérito de la patria expresa que se debe partir de la funcionalidad de las palabras y poner su enseñanza al servicio del pensamiento y de la emoción:

Se han necesitado los estudios de comparación de las lenguas, hechos desde el descubrimiento del Sánscrito, para que los gramáticos se hayan atrevido a tratar de las funciones de las palabras y, más adelante, a estudiar las palabras como elementos puestos al servicio de las diversas funciones del pensamiento $y$ de la emoción. Por largo tiempo se enseñó la pétrea estabilidad de la palabra, las diez inflexibles partes de la oración, los mismos elementos constitutivos de la sintaxis. Ni la pasión o el simple impulso emotivo, que tan sutilmente transforma la expresión oral, se reconocieron en el estudio de la Gramática. Ha sido como si no existiesen.

Por desgracia, la enseñanza de la Gramática, muy particularmente en las escuelas primarias y secundarias, continúa haciéndose como en la Edad Media, o como en el Renacimiento. Se han renovado en algunas escuelas los métodos de presentación, pero la doctrina se ofrece como si no hubiese transcurrido ya casi un siglo desde que se rejuvenecieron sus principios. La Gramática funcional existe, mas en la enseñanza habitual se desconoce.

Tal es el mérito de la obra que se tiene en las manos. $\mathrm{Su}$ autora (...) ha realizado una feliz tentativa de dar frescura y juventud y atractivo a estos estudios (...). Las comparaciones son gráficas y tomadas de la vida ambiente. (...) La autora (...) se ha impuesto la muy meritoria labor de hacer sencillo e inteligible, sin infantilizarlo, el material que no puede dejarse en manos de aquella misma juventud a causa de sus intrínsecas dificultades (p. IV-V, énfasis agregado).

De manera coincidente con Hernán Zamora, según se planteó en las líneas anteriores, Brenes Mesén, como pensador de la época, expone una pauta en la que se urge a supeditar, al servicio de la comunicación, la enseñanza de las palabras, para lo cual se debe partir de la vida ambiente. Señala, además, el desfase entre los avances de la disciplina y su aplicación pedagógica; desfase que persiste aún hoy.

\section{Claudia Cascante de Rojas: una propuesta didáctica y filológica}

En la introducción de su libro Castellano (1946), Cascante propone dos ideas básicas que a continuación se destacan:

- El aprender debe ser "deleitoso", como recurso didáctico que garantice la comprensión del lenguaje:

Ante mis alumnas, no pocas veces se ha albergado en mi mente el escollo de algunos principios gramaticales. ¿Cómo enseñarlos, entonces? ¿Cómo hacer que la comprensión los sostenga con firmeza? Y he urdido el plan: no voy a hablar con ellas, sino con mi hijo. ¿Cómo entendería él, en su mundo tan pequeño, lo que es un adjetivo, un verbo, un sustantivo? Y he de hacerle comparaciones, de suyo tan pueriles, que quizás le sean amables; dibujos que, tras un fin, lo induzcan también al arte; citas que se le conviertan en juguete, fácilmente destrozables o inocentemente amados, mientras un poder divino, algo así como de orfebre, incruste en su cerebro, cual una gema valiosa, la lógica de todos aquellos conocimientos que he querido darle. Y éste es el único recurso pedagógico con que inicio la publicación de algunos libros míos. Recurso que deseo se torne en el "aprender deleitoso" de que habla Gabriela Mistral (p. VIII).

- El material debe ser de fácil comprensión:

Por eso las lecciones de mi libro, que muy lejanas están de emprender altos vuelos, las he despojado de todo amaneramiento; he procurado dejarlas espontáneas, sin trabas de frases elegantes, períodos rotundos, ni galas de atildados escritores (id.).

A pesar de los objetivos planteados, la obra no escapa al iberocentrismo y conservadurismo ideológico que decía haber superado. Basta con observar sus "Ejemplos de voces sinónimas". Entre otros, proporciona algunos sin ningún miramiento sincrónico, estilístico o dialectal:

Borracho, temulento, espita

Alondra, alauda, aloeta, alhoja

Boda, himeneo

Zorra, raposa, vulpeja

Jilguero, cardelina, pintacilgo

Diablo, pateta, patillas

Sediento, sitibundo

Infierno, averno, báratro, gehena, orco, tártaro

(p. 116-117). 
Sin una razón o fundamento objetivo, hace comentarios axiomáticos como este, en el que trasluce criterios esteticistas sin tomar en cuenta aspectos ni fonológicos ni diacrónicos: "¡Qué fea palabra es el modismo costarricense "jartón” en vez de "glotón"!" (p. 120).

En Tesis de Gramática Castellana para Bachillerato, de la misma Claudia Cascante (1964), se evidencian las corrientes de la época. Siendo así, se plantea la condena de usos reales y se privilegian usos librescos, a pesar de que han pasado 20 años desde la propuesta de Hernán Zamora. Como muestra, baste su afirmación de que "No se admiten calientísimo, fuertísimo, nuevísimo, buenísimo, sino calentísimo, fortísimo, novísimo, bonísimo" (p. 8).

Expresiones propias del uso costarricense se plantean como "curiosidades" o "vicios":

"En Costa Rica hay curiosas especializaciones [semánticas]:

Se dio a la bebida (al licor) (sic)

Se hace olla todos los días

Comen gallo pinto

El campesino come tortilla (de masa)" (p. 42).

Hay que aclarar que "bebida" por 'licor' no constituye costarriqueñismo, sino que es una especialización pandialectal hispánica. Por otra parte, en "gallo pinto" se observa un fenómeno diferente; no es un caso de restricción semántica.

Continúa Cascante:

Vicios por elipsis:

Hincarse de rodillas (sic)

¿Idiay? = ¿Y de ahí que sigue?

¿Quiubo? = ¿Qué hubo de aquel asunto?

Voy obligada $=$ Voy obligada a sacar una nota mayor de seis (p. 44).

"Hincarse de rodillas" fue la forma usual en los orígenes del idioma. Gracias que sufrió elipsis quedó acuñado el univerbal "hincarse" para denotar esa acción. Al día de hoy, la expresión original "hincarse de rodillas" resulta redundante. El problema es que la autora está aplicando una consideración diacrónica en un corpus sincrónico.

\section{Segunda mitad del siglo XX: primeras dos décadas marcadas por el acento en las ejecuciones comunicativas y funciones sociales del lenguaje}

\section{Emma Gamboa: los silabarios, libros de lectura y la regionalización temática}

La Dra. Emma Gamboa, en el artículo "Libros de texto básicos para la enseñanza de la lectura" (1977), plantea que los textos principales para la enseñanza de la lectura básica en Costa Rica en el XX habían sido: El nuevo silabario, Lectura activa, y Paco y Lola.

Señala Gamboa que, en virtud del método global que introdujo en Costa Rica el maestro Omar Dengo, nace El nuevo silabario seguido por Lectura activa. Más adelante aparece el célebre Paco $y$ Lola, de la misma Emma Gamboa.

Vale la pena aclarar que $\boldsymbol{E l}$ nuevo silabario y el libro Paco y Lola son producciones para los niveles iniciales de la lectoescritura, esto es, el primer año de primaria. Ya en estos, y principalmente en el Paco y Lola, se observan criterios de organización y de gradación del léxico en cuanto a contenidos semánticos y estructura silábica de las palabras. Además se controla la extensión de los sintagmas.

En palabras de la propia Gamboa:

El libro Paco y Lola se diferencia de otros libros de texto globales centroamericanos y norteamericanos, hasta donde la autora conoce y puede juzgar, en que se somete, no solamente a una gradación de contenidos semánticos por extensión de oraciones e introducción progresiva de vocablos nuevos, sino también a la gradación de vocabulario por estructura silábica, de acuerdo con las características particulares de la lengua castellana (p. 15) 
Para ejercitarse en la lectura después de haber superado el primer nivel, se utilizó Lectura activa y, posteriormente, La casita del monte, también de la autoría de Gamboa.

Respecto de La casita del monte, Gamboa refiere:

Al estilo necesariamente sobrio se le ha dado un matiz poético. El vocabulario está escogido en forma deliberada de modo que enriquece el lenguaje de los niños con vocablos de valor semántico relacionados con el ambiente natural y social (...). Tanto los contenidos como las ilustraciones tienen validez genuina, porque se han motivado ambos en paisajes y en escenas verídicas. Este libro se cita solamente con el fin de ofrecer un ejemplo ilustrativo de lo que puede hacerse con temas locales. En vez de gastarse la mollera inventando lecturas sueltas y artificiosas, que se suponen atractivas para los niños y que se juzgan fáciles porque son pueriles, el autor de libros de texto puede hallar en su propio ambiente o región temas llenos de vida e interés humano (p. 15-16).

Se elaboraron lecturas con temas "reales" y, por tanto, se incorporaron vocablos relacionados con el ambiente natural y social. Se observa un viraje consistente a lo autóctono y a la experiencia e intereses de la niñez costarricense.

En síntesis, destaca en la producción de Gamboa la incorporación de una metodología más científica para el aprendizaje de la lectoescritura, y la incorporación del ambiente nacional.

\section{Mario Fernández Lobo e Isaac Felipe Azofeifa: el poeta y el filósofo abogan por el uso de la lengua como instrumento de comunicación, reflexión y pasión}

Mario Fernández Lobo, fiel exponente de la tendencia de la época, en "La moderna enseñanza de la lengua y los libros de texto de español" (1977), explica que los más modernos libros de enseñanza-aprendizaje del lenguaje son los "destinados al desarrollo de las habilidades expresivo-receptivas" (p. 31). Cita como ejemplo la serie de Libros del idioma, de la Editorial Fernández-Arce, de uso muy generalizado en el país en la educación secundaria del momento. Según manifiesta, se diferencian de los tradicionales en que:

...están redactados como instrumentos de aprendizaje para uso de los alumnos, se sustentan en una adecuada exploración de sus intereses, y tienen muy en cuenta las características del medio socioeconómico y cultural en que esos estudiantes se desenvuelven (id.).

Es valiosa la observación de Fernández sobre la necesidad y las limitaciones para trabajar los libros de texto, de manera científica, con vocabularios más acordes a las realidades:

Por "vocabulario básico" se entiende la lista de palabras (o aun de expresiones) que constituyen el sustrato lingüístico común, o de mayor empleo, entre los individuos de un grupo socio-cultural en determinada escala de desarrollo o actividad humana. Por tanto, puede darse un "vocabulario básico" de niños de 7 a 9 años, como también de campos técnicos (electricidad, mecánica automotriz, etc.), un "vocabulario básico" campesino, o de grupos marginados suburbanos, etc. La lista es interminable. Y esto mismo nos obliga a situar el problema en términos de investigación. No hay, todavía [1977], suficientes indagaciones en este campo. (...) En Centro América, por ejemplo, está en una etapa de incipiente desarrollo. (p. 28).

El poeta y educador Isaac Felipe Azofeifa, en su artículo "Pasión de leer" (1977), incluye un apartado que denomina "Lengua, trabajo de todos". Allí expresa las siguientes ideas:

1- La lengua no se adquiere sólo en las clases de español sino que su aprendizaje recibe influencia del contexto en el que se desenvuelve quien la usa:

-Mire usted -me decía una profesora-, qué mal redactan y leen los jóvenes. ¿Qué hace la Universidad? Los profesores de Castellano son los responsables". He escuchado muchas veces lo mismo. Y siempre he contestado: “-Usted se equivoca. Todos somos profesores de lengua castellana. La madre, que enseña las primeras palabras al niño; el círculo familiar, que rodea al niño hablándole mientras se le acaricia 
o se juega con él; los maestros de preescolar, de su primaria; todos los profesores de su segunda enseñanza; todos los profesores de su vida universitaria; pero también el periodista que redacta su gacetilla, o el escritor con su libro o su artículo; y el político, y el cura... Todo aquél que se para frente a nosotros y nos dirige la palabra es nuestro maestro -involuntario maestro- de la lengua que hablamos, del párrafo que escribimos. Observé a menudo, en mi práctica de profesor, que los estudiantes que vienen de familias con tradición de cultura muestran riqueza de palabras, correcta sintaxis, uso propio de los términos. El hijo de familia obrera o campesina, si no ha atinado a hacer conciencia de su deficiencia de lenguaje, revela la pobreza de vocabulario, sintaxis tortuosa, impropiedad y oscuridad en los términos. La educación de nuestra habla es primero un proceso inconsciente, espontáneo, reflejo, que se realiza dentro del medio social en que crecemos. (p. 76).

2- Para que el alumnado crezca en riqueza lingüística, la respuesta adecuada no es el facilismo, sino la reflexión y el análisis:

Obviamente, la tarea del profesor de castellano consiste en sistematizar conocimientos; hacer ciencia del lenguaje para crear la conciencia crítica de la expresión; estimular el desarrollo de la sensibilidad mediante el manejo estético de la lengua; formar hábitos de expresión correcta; promover la autenticidad en el uso de la lengua como patrimonio espiritual de la comunidad; etc. Entonces, ¿cuál es la responsabilidad concreta de los demás profesores, por ejemplo del que enseña matemática o ciencias? Enseñar el lenguaje de la matemática, el de las ciencias (...). Contrariamente a esto, se suele escuchar a profesores que payasean, o manejan un lenguaje de pachucos para explicar un tema de su especialidad. Y se despreocupan del uso preciso, propio, claro de los términos matemáticos o científicos. En realidad, ni son hombres de ciencia, ni son profesores. La educación está llena de charlatanes, de irresponsables que tomaron el camino de la educación para ganarse un sueldo... (id.)

3- La enseñanza de la lengua ha puesto, erróneamente, el énfasis en el texto literario:

Una errónea concepción de la enseñanza de la lectura y la redacción nos ha llenado de libros de enseñanza con modelos exclusivamente literarios. Estos libros sólo cumplen un objetivo: enseñar el manejo de formas estéticas. Un libro con modelo para la lectura debiera traer muestras de prosa científica, filosófica, o del campo histórico, o explicaciones sobre cómo se lee un gráfico, un mapa, el dibujo, la fotografía en una página del libro de biología, psicología, sociología, etc. (id.)

Aunque la propuesta de Azofeifa (1977) insta a tener en cuenta otras modalidades del discurso, aparte de la literaria, lo cierto es que continúa supeditada a lo escrito.

\section{Dos proyectos oficiales}

Ha sido una práctica sostenida en el sistema educativo de Costa Rica que las obras se presenten al análisis del Consejo Superior de Educación, a fin de que éste las avale y recomiende su uso en las escuelas y colegios. Antes de 1968, los libros de texto eran elaborados por escritores independientes que sometían sus obras a este proceso. Entre los textos que más se usaron antes del 68 estaban: Silabario Castellano de Porfirio Brenes Castro, Paco y Lola de Emma Gamboa, y Madre América de Adela Ferreto y Carlos Luis Sáenz.

En esta, como en todas las épocas, hubo iniciativas privadas. No obstante, a continuación se hará referencia a los proyectos de libros de texto oficiales, entendidos como aquellos en cuyo proceso de elaboración y distribución estuvo presente el Ministerio.

\section{- Programa ODECA-ROCAP}

Entre 1968 y 1978, se llevó a cabo el Programa ODECA-ROCAP (Organización de Estados de Centroamérica y Panamá), mediante el cual se dotó de libros de texto a las escuelas públicas del área. Estos textos incluían las guías correspondientes para uso del docente, pero no eran específicos del país; y por esta misma razón no serán objeto del presente estudio. Como información general, hay que recordar que Flora Ovares (1977) analizó los textos de ODECA-ROCAP y demostró que están permeados de una 
visión ideologizada, responden a esquemas míticos y maniqueístas, le dan relevancia a lo anecdótico y accesorio para disfrazar los conflictos sociales. Modelan la conducta de acuerdo con los intereses de la clase dominante y del polo imperialista.

\section{- Serie Hacia la Luz}

En 1985 el Ministerio de Educación Pública inició un nuevo programa de elaboración de libros de texto, con el financiamiento de la Agencia Internacional para el Desarrollo (AID) de Estados Unidos. El producto derivado de este proyecto fue la serie de libros Hacia la Luz, con sus correspondientes guías. Esta serie abarcó las cuatro asignaturas básicas y cada año escolar de primaria. El planeamiento y elaboración de los libros estuvo a cargo de equipos de especialistas del país, contratados por el MEP. Durante los dos primeros años de existencia del programa se distribuyeron, aproximadamente, dos millones de libros en las escuelas públicas. A la par de estos esfuerzos gubernamentales se continuó con la comercialización de libros de texto en manos privadas. El vacío que dejó el hecho de que la Serie no se reimprimiera favoreció el incremento de la circulación de libros -algunas veces superficiales adecuaciones- de editoriales privadas, nacionales y extranjeras.

En relación con el tratamiento del léxico, hay que decir que estos libros son de conocimientos generales de la lengua y la literatura. El léxico se incorpora ancilarmente.

Ya se puede hablar de una transición, no completa aún, en la que la serie Hacia la Luz marca una norma no iberocentrista (se incorporan unas pocas palabras vernáculas, como "cas"). Aunque hay silencio respecto del paradigma pronominal del voseo, se toma en cuenta al menos indirectamente en una ilustración que introduce el tema de los homófonos "vos - voz" (p. 83 de Español $6^{\circ}$ ):

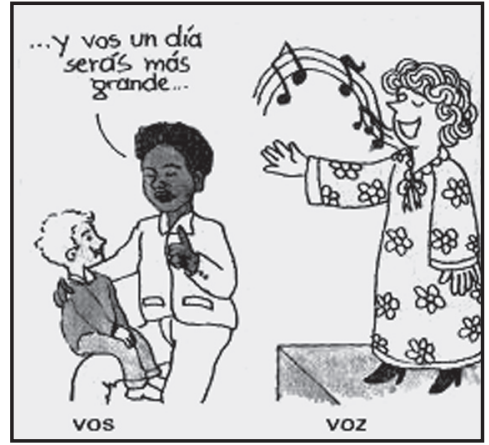

MEP. Serie Hacia la Luz. Español $6^{\circ}$

Se incorpora el registro oral, sin dejar de supeditarlo a un registro escrito monolítico, no adaptable a las diferentes interacciones humanas. Por ejemplo, cuando se propone corregir textos tales como "Es cierto, ayer lo dijo Humberto: el que no está vivo está muerto", se está equiparando la mera repetición de sonidos con la inadecuación de la cacofonía. Lo cual se agrava con la exigencia de controlar dicho fenómeno en el habla oral. La ilustración de la página $92\left(\right.$ Español $\left.4^{\circ}\right)$ problematiza una emisión radiofónica (por tanto, cien por ciento oral) que a la letra dice: "Es la emoción que siente mi corazón al oír tu canción". Por ninguna parte se hace la salvedad de que en el registro oral espontáneo las construcciones del tipo "Lucho cortó mucha madera con el serrucho" suelen pasar inadvertidas, gracias a que lo comunicativo priva sobre lo estético.

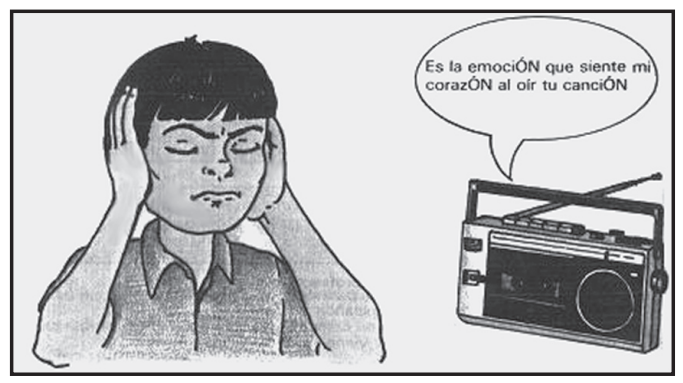

MEP. Serie Hacia la Luz. Español $4^{\circ}$. 
Se utilizan nociones científicas morfológicas. En la página 78 de Español $4^{\circ}$ se presenta un caso de análisis morfológico que, por fin, parece ser acorde con la distinción entre sufijo derivativo y sufijo flexivo (distinción que ha sido sistemáticamente ignorada en la enseñanza primaria y secundaria costarricense, aun en nuestros días). Se trata de la raíz zapat-, a la cual se le unen las siguientes posibilidades: $-a z(0)$; -er(o); -it(o). Efectivamente, el paréntesis que encierra la marca de género parece ser un indicador de su naturaleza diferente a la del morfema derivativo que le antecede. No obstante, esta visión satisfactoria no se sostiene de modo consistente, pues en la misma página, respecto de la raíz camp-, se ofrecen las opciones de -esin(o) e -iña (para dar como resultado "campiña"), tratada esta última parte como una unidad indivisible, cuando lo cierto es que involucra la marca de género femenino $\{-a\}$.

Otro tanto se puede comentar del juego que aparece en la página 93 de Español $4^{\circ}$. Allí se presentan seis grupos de miembros de diferentes familias léxicas; sin embargo, los autores no se decidieron por un único criterio de agrupación para tales familias. Obsérvese:

$\begin{array}{ll}\text { hidr- } & \text { hablar } \\ \text { hidráulica } & \text { hablador } \\ \text { hidrógeno } & \text { habladuría } \\ \text { hidrosfera } & \text { hable }\end{array}$

En el caso de "hidr-" tomaron la raíz -aquí considerada como si fuera un prefijo-. Pero en "hablar" tomaron el paradigma verbal (a pesar de que dos de los derivados que proporcionan: "hablador" y "habladuría”, son nominales). Habría sido preferible que se enfocaran en la raíz habl-, con lo cual habrían revestido su práctica de mayor coherencia.

En respuesta a esta misma transición, la serie ya está encaminada en una orientación más científica y descriptiva que normativa, si bien con rigurosas excepciones como la de la página 73 de Español $6^{\circ}$, donde se desacredita el lenguaje popular con estos términos:

En los diálogos que se dan, la conversación campesina se manifiesta en lenguaje popular. (...) En muchas ocasiones pronunciamos mal las palabras (...). No es conveniente usar expresiones populares porque: -Demuestra descuido por la lengua. -Indica despreocupación por la expresión. -Refleja falta de interés por conocer el tipo de receptor a quien se dirige. (...) Elabore una lista de vocablos que, en algún momento, usted haya escuchado o pronunciado mal y que, por tanto, es conveniente corregir.

Paradójicamente, ese juicio de que "refleja falta de interés por conocer el tipo de receptor" es mucho más aplicable a una postura maquinalmente inflexible, como la demostrada en esta ocasión por los redactores de la Serie.

Un último ejemplo de esa mezcla de perspectivas, propia de un estadio transicional, que se detecta en algunos contenidos de Hacia la Luz, tiene lugar en el trabajo de campo que se asigna a los alumnos en la pág. 103 de Español 6. Las instrucciones consisten en anotar "a.) Expresiones populares. b.) Palabras mal dichas. c.) Vocabulario propio de la región". Semejante heterogeneidad resulta contradictoria, porque las palabras catalogadas como "mal dichas" ¿lo son desde qué punto de vista? Si se pretende usar la norma ibérica como parámetro, entonces el criterio científico queda anulado, pues bajo la etiqueta de "mal dicho" habría que encajonar todas las variantes geográficas, sociolectales y estilísticas que se alejen de esa norma. Si, por el contrario, se va a privilegiar un enfoque científico, necesitarían partir de la premisa de que no hay nada "mal dicho", a no ser una pseudoforma o algo que carezca de valor comunicativo para los hablantes; algo que no puedan decodificar (esto incluye, por supuesto, elementos de vocabulario ajenos a su realidad dialectal o diastrática).

En cuanto a la propuesta metodológica, se observa ya un acercamiento a métodos inductivos. Esta nueva tendencia se ilustra con la página 45 de Español 4, la cual aborda el tema de los adjetivos de 
la siguiente manera: Se focalizan algunas frases de un texto que los estudiantes previamente han leído, y se pregunta "¿Cómo es?”, “Cuántas son?”, y “Cuál es?”, buscando que contesten con esas frases focalizadas. Después de haber enfrentado al niño a estos análisis, se le proporciona la explicación funcional: "Si usted es cuidadoso se habrá dado cuenta de que todas las palabras enmarcadas se añaden al nombre para expresar una cualidad del ser o cosa, o para agregarle una determinación o una relación". Por último, proporcionan el metalenguaje: "Estas palabras se llaman adjetivos".

Ya se observa en esta serie una preocupación por manejar criterios de inclusividad étnico-cultural y etaria. Muchas de las ilustraciones representan a personas de diversas etnias en interacción cercana, por ejemplo, en la página 102 de Español $6^{\circ}$ :

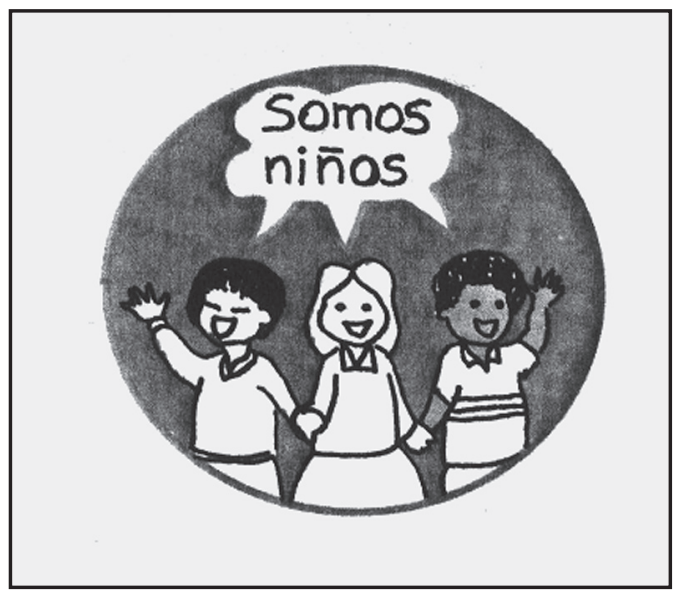

Hacia la Luz refleja un esfuerzo encomiable por proponer el aprendizaje como un juego. Abundan las actividades con crucigramas, sopas de letras, laberintos, ruletas, caracoles y juegos de mesa afines, así como construcciones de textos a partir de viñetas o gags. Uno de los ejemplos se halla en la página 54 de Español $5^{\circ}$, la cual presenta una dinámica dentro de una familia de ascendencia afrocaribeña: se trata del juego de palabras del tipo "No es lo mismo A que B”: “...me río en el baño que me baño en el río"; "... José María de las Cañas que las cañas de José María", etc. Se contextualiza en un ámbito familiar, donde participa desde el miembro más pequeño hasta la tercera generación (abuelos), haciendo un rescate del humor sano.

En resumidas cuentas, a pesar de los yerros o limitantes que se han mostrado aquí, la Serie Hacia la Luz de 1985 es un caso paradigmático de un proyecto oficial (del Ministerio del ramo), colectivo -en el sentido de trabajo en equipo-, que respondía a toda una planificación o formación ad hoc, tendiente a enriquecer el producto desde el punto de vista de la actualización de las disciplinas, la comprensión de los procesos de aprendizaje en el niño, y los programas educativos del momento.

\section{Después de los 80. Etapa de los enfoques comunicativos o procesuales}

\section{Víctor Sánchez Corrales: una propuesta de planificación lingüística basada en la investigación de las competencias del estudiantado y de un perfil del hablante culto}

La línea de investigación ELEXHICÓs, creada por el Dr. Víctor Manuel Sánchez Corrales, estaba adscrita a la Escuela de Filología, Lingüística y Literatura de la Universidad de Costa Rica en sus inicios. Posteriormente, al fundarse el Instituto de Investigaciones Lingüísticas (INIL), la línea se incorpora a éste. Desde aquí el profesor Sánchez Corrales, liderando a un equipo, desarrolla una serie de investigaciones, algunas de las cuales liga de manera sistemática a la educación costarricense.

En el campo de la investigación lexicográfica y su aplicación a la enseñanza de la lengua materna, es justo destacar la labor pionera de este lingüista, quien ha desarrollado todo un aporte de formación, evidente 
en sus publicaciones y en la dirección de trabajos finales de graduación. De ahí que los estudios que más adelante se detallan son de su autoría o coautoría, o tienen una deuda con el mentor.

Por lo dicho, resulta fundamental detenernos en la propuesta de este académico costarricense:

1. Basado en una revisión histórica, sostiene que el concepto de lengua española que ha predominado en el sistema educativo costarricense se fundamenta en la doctrina de la Real Academia Española y, en menor grado, a partir de 1941, en las aportaciones teóricas de Andrés Bello, quien, aunque defiende el uso lingüístico de la gente educada de América, en esencia no plantea la existencia de normas diferentes y legítimas. En consecuencia, para la educación costarricense, se abstraen principios idiomáticos del uso lingüístico culto y se privilegia el discurso literario como recurso para enseñar a escribir y a hablar "bien" (Sánchez, 1993).

Siendo así, la norma académica se ha impartido en la escuela costarricense como el único modelo lingüístico por imitar, y las variaciones correspondientes al español de Costa Rica se consignan como vitandas.

2. Ante el panorama que describe, Sánchez propone que el modelo académico, en esencia saussureano, se sustituya por el modelo sociolingüístico, y la noción de "corrección idiomática", por la de adecuación comunicativa. Desde luego que estas sustituciones deben ir aparejadas con las correspondientes consecuencias en la planificación lingüística:

Enseñar español en la educación costarricense ha de ser enseñar las distintas variedades de español en Costa Rica, de modo que el educando pueda desenvolverse adecuadamente según la situación comunicativa. Una de las variedades por estudiar es la norma culta costarricense (Sánchez, 1993, p. 111).
3. Insiste en la necesidad de una labor conjunta de lingüistas y pedagogos:

... para contribuir a una adecuada planificación lingüística en lo relativo a la enseñanza-aprendizaje del español como lengua materna en el sistema educativo costarricense (Sánchez, 1995, p. 73).

4. Reitera que la educación debe proporcionar al educando la variedad del español que le permita la interacción verbal exitosa como garantía del progreso académico, social y económico. En este sentido, dos tareas deben abordarse:

- Como cualquier lengua, en el español costarricense se constata variedad de registros, lo cual obliga a emprender la tarea de codificar esas variedades en los distintos niveles, para lo que el trabajo de investigación es el primer paso.

- Otra labor educativa por realizar consiste en la eliminación de los prejuicios de educadores y alumnos sobre la norma académica y culta nacional. Es necesario que legitimicen dicha norma, como criterio de adecuación comunicativa en el contexto costarricense. Este reto debe tener consecuencias en la planificación lingüística (Sánchez, 1993).

5. De lo anterior se deriva que la enseñanza de la lengua debe fundamentarse en un adecuado programa de investigaciones lingüísticas: sobre variedades del español costarricense e, igualmente, sobre el uso lingüístico culto en el país, en su condición de variedad meta o lengua ideal de los procesos de enseñanza y aprendizaje.

El paso del modelo académico al sociolingüístico, la sustitución del concepto de 'corrección idiomática' por el de 'adecuación comunicativa' implica un cambio de saberes, de objetivos y de prácticas pedagógicas: estudiar cosas sobre la lengua en vez de la lengua, prioridad de la producción y decodificación del discurso respecto del conocimiento del metalenguaje, y 
política lingüística y elaboración de materiales didácticos, fundamentadas en la competencia comunicativa de los sujetos de la educación y no sólo a partir de la lengua literaria de ayer y de hoy. (Sánchez, 1995, p. 73).

En este contexto y para los propósitos de apoyar el cambio paradigmático, se debe estudiar la norma lingüística costarricense y la competencia lingüística de los educandos.

- Las investigaciones sobre el uso culto están en su etapa inicial. Según Sánchez (1995), para que éstas ganen en rigurosidad, se debe elaborar el perfil sociolingüístico del hablante culto costarricense y recoger un corpus representativo de sus producciones discursivas. Tarea urgente, que sólo el trabajo en equipo hará fructificar no tan tardíamente.

- Respecto de investigaciones sobre la competencia lingüística de los educandos, sostiene Sánchez (1995) que en materia educativa no se puede hacer caso omiso del sujeto de la educación:

La elaboración de los programas de estudio y de los materiales didácticos, la planificación de los procesos de aprendizaje y la organización de las actividades de adquisición de la lengua materna, deben fundamentarse en un conocimiento de la competencia lingüístico-comunicativa de los educandos, en los distintos componentes de la lengua: fonológico, morfosintáctico, léxico-semántico y en la competencia discursiva. (Sánchez, 1995 (74-75).

De acuerdo con Sánchez (1995), por medio de estudios longitudinales y trabajando con muestras representativas para que las investigaciones tengan validez nacional, la lingüística debe proporcionar un conocimiento global de la competencia que tienen preescolares, escolares y colegiales, en la respectiva etapa de ingreso. Esta área de investigación también está en una etapa inicial, pero, al momento (2005), ya hay algunos frutos.

\section{Marta Rojas: Participación en los programas de 1995 con una propuesta de cambio de paradigma en la enseñanza de la lengua}

En el año 1995, el Ministerio de Educación Pública lleva a cabo una reforma de programas de la Educación General Básica y Diversificada. En el caso de Español, además de incorporar en la Comisión encargada para tal efecto a asesoras nacionales y regionales de la asignatura, integra a esta Comisión a la profesora en servicio Amalia Vargas y, por las universidades, a las profesoras Ivonne Robles Mohs, Marta Rojas Porras -coautora de este artículo-, ambas de la Escuela de Filología, Lingüística y Literatura, y Nidia García Lizano, de la Escuela de Formación Docente. Las dos últimas, también investigadoras del Instituto de Investigaciones en Educación (INIE); todas de la Universidad de Costa Rica. La primera se ocupó del área de Literatura para el Tercer Ciclo y Ciclo Diversificado; la segunda trabajó el área de lengua y de lectura no literaria en estos ciclos, además de la temática completa desde el Primer Ciclo hasta el Diversificado. La tercera trabajó el Primer y Segundo Ciclos.

Con respecto a la enseñanza de la lengua, y como aporte de la participación de la Universidad, en estos programas se plantea un cambio de paradigma que reconoce la lengua como sistema integrado por componentes interrelacionados y sus actualizaciones en diversidad de variedades. Así, introduce nociones de sociolingüística, que favorecen el análisis del voseo en el paradigma verbal, en calidad de uso apropiado y no vitando; plantea el estudio del lenguaje del adolescente, por ejemplo. De esta manera, las variedades del español costarricense encuentran cabida digna en el ambiente escolar.

En relación con el léxico, éste se incorpora como componente de la lengua, con sus condiciones de variedad, precisión y propiedad para un uso adecuado. De igual 
manera que los componentes morfológico y sintáctico, el componente léxico interesa en función de su actualización en la expresión escrita y oral. En términos generales, plantea estrategias para la enseñanza del léxico, tal como su inserción en campos semánticos que muestren las redes que establece el significado.

En cuanto a esta experiencia, hay que aclarar que en la conceptualización del programa de 1995 y de los derivados de él (los de primaria se han alejado bastante de este avance y han adoptado una tendencia contenidista y no pragmática) se utilizaron textos sobre escritura y lectura -ya publicados en ese momento- de autoría o coautoría de Marta Rojas; no obstante, en ninguno de los documentos citados se anotó, como referencia bibliográfica, su procedencia.

\section{Libros de Español de la Serie Hacia el siglo XXI: Cristalización de los programas del 95 en un texto didáctico}

En 1996, se elaboró esta serie en una colaboración de la Universidad de Costa Rica y el Ministerio de Educación Pública. Los libros de español fueron coordinados desde el INIE por la investigadora Marta Rojas. A diferencia de su predecesora Hacia la Luz, esta serie incluía materiales desde la primaria hasta el $9^{\circ}$ año. Cada nivel de primaria se integra en un conjunto de tres libros denominado "complejo didáctico": Texto, Actividades y Guía didáctica, de manera que se pusieron a disposición de las escuelas del país 18 libros de español, y seis para secundaria. Lo expresado en las líneas siguientes atañe a los textos de primaria.

Este fue el primer proyecto que tuvo que adherirse a la política del lenguaje inclusivo, si bien de un modo parcial (todavía encontramos "el emisor", "el receptor", con sentido genérico abarcador). En ese momento histórico, el concepto de inclusividad poseía unos márgenes más estrechos que los de hoy, cuando opera un marco jurídico regulatorio.

En otro orden de cosas, el paradigma pronominal ha incorporado plenamente al voseo en un tratamiento tan válido como el resto de formas para la $2^{\mathrm{a}}$ persona. Aparece aplicado nominal y desinencialmente. Es decir que el proceso que apenas se vislumbraba en la Serie Hacia la Luz aquí aparece consumado.

Los libros de Español 1 y 2 (autoras: Nidia García y Nora R. de Chacón), como es de esperarse, hacen un énfasis en la adquisición de la lectoescritura. Con todo, ya se incorporan nociones gramaticales sin metalenguaje, y en sentido funcional -concretamente se trabajan los adjetivos calificativos, ya sean univerbales o pluriverbales, y sustantivos adnominales (adjetivos por función). Generalmente se les refiere a caracterizar personajes o ilustraciones. Hay también trabajo de sinonimia y campos semánticos:

"Lo mismo o casi lo mismo":

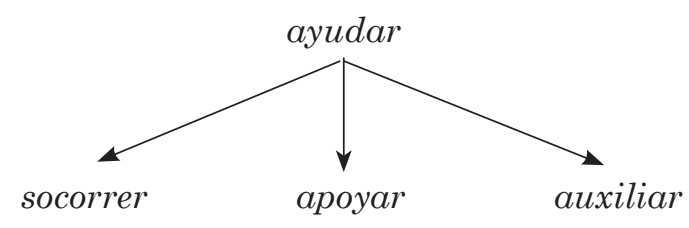

"Palabras relacionadas":

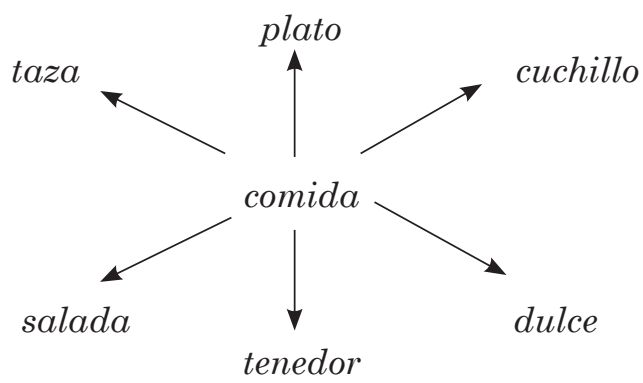

La definición de sílaba en la página __ de Español 3 (autoras: $\mathrm{M}^{\mathrm{a}}$ de 
los Ángeles Castro e Isabel Ducca) como "esfuerzo de voz" no es precisamente la más satisfactoria desde el punto de vista de la exactitud científica, pero sí se sostiene en función de los propósitos didácticos. Posee el mérito de que, para la división silábica, acentuación y demás conocimiento prosódico, se parte de la dimensión oral y no ancilarmente de la escrita, como había sido la tónica.

El ánimo de interactuar con los lectores -de privilegiar la función apelativa o conativa, antes que la referencial- se trasluce en un lenguaje más cercano a lo coloquial cotidiano, de tinte jocoso. Así, en Español 3, p. 20: “iResultó respondón!" -supratítulo para introducir la fábula de "El mujik y el caballo" de Tolstoi. "iSe me lengua la traba!" (p. 30)-para introducir el tema de los trabalenguas. La "Balada de doña Rata" (p. 72) está supratitulada "Pipiriciega y perdida". En respuesta a esta misma intención, aparece un "yo" o estilo subjetivo por parte de las autoras en determinados pasajes de la teoría o instrucciones: una forma de persuasión que se había considerado inusitada en un texto de naturaleza no literaria. Por ejemplo: "Mi amigo y yo comenzamos a buscar palabras que tuvieran acento en la penúltima sílaba, y imire las que encontramos! (p. 41).

También algunas de las aportaciones literarias vienen enmarcadas en la realidad de nuestro medio. El texto anónimo que se titula "Esos oficios" involucra léxico como el siguiente: "¡Qué guaba!” (p. 58), "Le decían que le cantaba la gallina" (p. 58), "¡Quien la veía!" (p. 60).

En las instrucciones de uno de los ejercicios de este libro de Español 3 (p. 75), se induce a los educandos a que le pongan ritmo de rock, tango o rap a uno de los textos literarios. Es un esfuerzo por abrir la práctica escolar a manifestaciones que, hasta entonces, se habían considerado poco menos que prohibidas (únicamente se reconoce un antecedente en este sentido, que es Rojas, Marta y Ducca, Isabel: Despertando a las palabras, de 1993).
Como ejemplo de la derivación de palabras, Español 3 ofrece esto:

"Conejo coneja" (p. 84). Lo cierto es que ya constituye un anacronismo encontrar eso allí, en 1996. Están equiparando la raíz, que es atada: $\{$ conej-\}, con la forma flexionada en género masculino. Es decir que extrañamente se considera la forma masculina como la más básica o primitiva, cuando en realidad ninguno de esos dos presupuestos se cumple: ni "conejo" es raíz, ni "coneja" es nombre derivado. Ambos son nombres flexionados.

Desde la perspectiva de las autoras Castro y Ducca, el uso del diccionario se recomienda como una actividad apriorística o previa al acto de leer, de manera que, mediante estar interrumpiendo la lectura fluida para irse a consultar los significados desconocidos, no se inhiba el placer y el goce que pretende propiciar la lectura creativa.

En Español 4 (Isabel Ducca y Yadira Mora), es novedoso encontrarse por fin el reconocimiento de que el lenguaje necesita una adecuación de estilos -formal e informal-, con las implicaciones que eso tiene para el nivel léxico, en vez de la pretensión irrealista del lenguaje monolítico o inmutable, que había recibido un tratamiento de axioma en los trabajos didácticos sobre lenguaje en Costa Rica. Mora y Ducca lo plantean así: "¿Alguna vez le ha sucedido a usted algo parecido: estar en un lugar donde se deben guardar las distancias formales, y estar necesitado de una conversación informal y cariñosa?..." Estimulan a que el niño construya un escenario en el que deba hacer las adecuaciones del caso.

En los libros a partir de $4^{\circ}$ se habla ya explícitamente del campo semántico; incluso, ciertos ejercicios -como el de Español 4, p. 59- consisten en que los niños hagan una caracterización por semas (sin caer en una enseñanza de metalenguaje). Otros análisis inductivos, presentes en el libro de Español 6 (Marta Rojas e Isabel Ducca), se orientan a determinar la "palabra intrusa" en campos semánticos dados. De tal manera 
se introduce el estudio del léxico como sistema, y en la correspondiente Guía para el maestro de $4^{\circ}$ se definen estos importantes conceptos.

En estos años todavía se daba una vacilación sobre cómo incorporar al castellano didáctico numerosos vocablos del argot tecnológico. Así, en Español 6 se presenta como "impresor" el artefacto que en Costa Rica se conoce generalmente como femenino: la impresora. Y más problemática aún es la estrategia a que se recurre para evitar el calco o préstamo del inglés mouse: en este libro se opta por denominarlo "escoba o palanca de mandos", al margen del uso comúnmente aceptado.

En consonancia con la óptica funcionalista, en Español 6 se afirma que "El orden de los factores sí altera el producto", de tal suerte que la topicalización o rematización ejercen inevitablemente un efecto sobre el contenido del discurso, lejos de ser fenómenos intrascendentes.

Otro de los avances que se hacen patentes en esta serie con respecto a donde habían llegado sus antecesores es una visión más realista sobre la sinonimia, menos absolutista. Dice en la Guía didáctica 6 :

Es importante que usted recalque que los sinónimos expresan significados parecidos pero no equivalentes. Así, por ejemplo, viejo y anciano son sinónimos, y se puede construir "casa vieja" - "hombre anciano"; pero no es aceptable "casa anciana", porque anciano solo se puede aplicar a aquellas palabras que se refieren a lo animado (animales y humanos).

Añadido a esto se habla de la sinonimia sintáctica.

De modo similar, se promueve la noción de antonimia como vocablos de significados no necesariamente contrarios entre sí, sino más bien complementarios y graduables.

Cabe resaltar que el componente léxico se trabaja incorporado en textos, no como palabras aisladas. La mayoría de los ejercicios solicita que el estudiante reelabore los textos, manteniendo el mismo sentido (sinonimia) o expresando sentidos alternativos (antonimia). Como lo plantea uno de los subtítulos de la Guía didáctica 6: "Un repertorio de palabras es un repertorio de sentidos".

\section{Marielos Murillo Rojas: el léxico debe abordarse de manera integrada y partiendo de la experiencia de los niños y las niñas}

Murillo Rojas, quien trabaja en equipo con el Dr. Sánchez, en La enseñanza del vocabulario en la educación general básica: propuesta metodológica (1999), sobre la base de algunos teóricos y de sus propias reflexiones, propone objetivos para la enseñanza del vocabulario para los preescolares y escolares de Costa Rica (p. 156):

Fijar y consolidar los vocablos ya conocidos por el niño.

Corregir las deficiencias e incapacidades específicas que puedan plantearse.

Establecer claramente las diferencias de los distintos vocablos según la situación comunicativa.

Proporcionar experiencias que conlleven al estudio o incorporación de un vocabulario general de comunicación.

Capacitar para percibir los distintos matices de significación con que puede ser empleada una misma palabra, según el contexto de enunciación.

Plantea la autora que la adquisición y el uso del vocabulario se optimizan mediante aprendizajes formales, experiencias vividas y contactos con temáticas diversas. Por tanto, su enseñanza debe abordarse de manera integrada a todo el currículum escolar, pues su función no es sólo ampliar el bagaje léxico sino, principalmente, favorecer la competencia léxica. El dominio del vocabulario consiste tanto en el conocimiento de las palabras, de los conceptos a los cuales se refieren, como en el uso eficaz y adecuado, según las situaciones (p. 160):

En síntesis, la situación de aprendizaje cuyo objetivo sea enriquecer la competencia léxica debe ampliar el 
vocabulario activo y pasivo y tomar en cuenta el criterio de uso de cada palabra en relación con el registro, precisión, connotaciones, estilo, etc.

En resumen, como propuesta metodológica para la enseñanza y aprendizaje del léxico, Murillo plantea (p. 161):

1. Revitalizar el uso del diccionario en el aula, según los criterios de Garrido Moraga (1991) y Maldonado (1998).

2. Basarse en las experiencias de los niños y ubicarse en contextos determinados, para lo cual es pertinente el estudio de campos semánticos. En esta estrategia se puede trabajar el vocabulario según diversas relaciones: de inclusión, de pertenencia, de asociación, de parecido, de uso, de situaciones, etc. Además, familias de palabras, sinónimos, homónimos, etc.

3. Estudiar el vocabulario por medio del análisis de rasgos semánticos permite partir de los conocimientos previos del alumno, y de su forma de almacenamiento y recuperación. Este tipo de análisis da cuenta de las relaciones entre conceptos de una misma categoría y, al mismo tiempo de la singularidad de cada palabra; de esta manera favorece la precisión semántica.

4. Elaborar esquemas y organigramas tales como mapas semánticos, boletines y fotomontajes.

5. Incorporar el uso de juegos lingüísticos: sopas de letras relacionadas con algún campo semántico, cadena de palabras siguiendo una consigna, invención de nuevas palabras y sus significados, adivinar palabras a partir de preguntas, crucigramas, bingos de palabras, trabalenguas, chistes, etc.

6. Lectura de textos significativos para el educando.

\section{Marta Rojas: La definición de un léxico meta para cada año de la escuela costarricense}

Con base en investigaciones de léxico básico escolar costarricense (léxico que se conoce), llevadas a cabo por Sánchez, Murillo y Rojas, y el léxico de los libros de texto de la Serie Hacia el siglo XXI (léxico que se debe conocer), Rojas ha determinado un repertorio léxico por enseñar en cada grado escolar. Para la incorporación de ese léxico en la competencia lingüística de los niños y las niñas propone estrategias que privilegian el análisis de las relaciones entre significados de las palabras, la producción de textos y el ludo como la manera natural de aprender jugando. Esta propuesta, en la que actualmente se trabaja, se concretará en material didáctico en soporte digital e impreso.

\section{Conclusión}

El panorama general mostrado pone en evidencia la constante preocupación sostenida en el país por la enseñanza de la lengua, por la incorporación de nuevas metodologías y por el apoyo con los textos didácticos. Aunque algunas de las propuestas no se concretaron en prácticas congruentes y los esfuerzos oficiales del 95, con los programas y los libros, aparentemente se perdieron por presiones políticas, para los tiempos actuales se mantiene un dinámico trabajo científico. De esta manera, los sustentantes de este artículo ponen la esperanza en que las investigaciones actuales brinden criterios objetivos y actualizados que sean tomados en cuenta por quienes se encargan de la planificación lingüística.

El cambio de los ambientes de aprendizaje de la clase de español -donde lo que se enseñe esté acorde con los avances de las disciplinas que la sustentan, y con los intereses y los modos de aprendizaje de la 
niñez- está urgido de un trabajo conjunto entre lingüistas y pedagogos. Las posposiciones de esta demanda perjudican a las universidades, cuyos graduados deben enfrentarse a una suerte de frustración por las barreras que para la innovación les impone el sistema, y el personal docente del Ministerio se ve privado de una capacitación actualizada, realista. La consecuencia más grave recae sobre la niñez costarricense que tiene que conformarse con una clase de español aburrida, descontextualizada, y sin retos para crecer. Por todo esto: No más tiempos de desarticulación. Sí, tiempo para la colaboración.

\section{Referencias bibliográficas}

Araya, Kattia. (2001). "La enseñanza del léxico en los programas de estudio de español del tercer ciclo (1971-1995)". Káñina, Revista de Artes y Letras de la Universidad de Costa Rica. XXV (2).

Azofeifa, Isaac Felipe. (1977). "Pasión de leer". En: Revista Educación de la Universidad de Costa Rica. I (2).

Cascante de Rojas, Claudia. (1946). Castellano. Sin más datos.

Castellana para (1964). Tesis de Gramática
Lehmann, San José.

Castro Villalobos, Ma. y Ducca Durán, Isabel (1996). Español 3. Serie Hacia el siglo XXI. MEP/EUCR. San José.

Ducca Durán, Isabel y Mora Alfaro, Yadira (1996). Español 4. Serie Hacia el siglo XXI. Ministerio de Educación Pública. San José: Editorial Universidad de Costa Rica.

Elizondo Zamora, Hernán. (1942). Educación de la lengua materna. San José, sin dato de editorial.
Fernández Lobo, Mario. (1977). "La moderna enseñanza de la lengua y los libros de texto de español". En: Revista Educación de la Universidad de Costa Rica. I (1).

Gagini Chavarría, Carlos. (1902). El lector costarricense. Heinrich y Cía., Barcelona.

. (1897). Vocabulario de las escuelas. Tipografía Nacional, San José.

Gamboa, Emma. (1977). "Libros de texto básicos para la enseñanza de la lectura”. En: Revista Educación de la Universidad de Costa Rica. I (1).

García González, Francisco. "El Catón" en Enciclopedia de los recuerdos. Website: http://www.teacuerdas.com

González, Lilia y Quesada, Manuel Clemente. (1930). Selección de palabras para ortografía. Imprenta Tormo, San José.

Haensch, G. y otros. (1990). La lexicografía. De la lingüistica teórica a la lexicografia práctica. Madrid, España: Biblioteca Románica Hispánica Gredos.

Lomas, Carlos. (1999). Cómo enseñar a hacer cosas con las palabras. Barcelona: Paidós.

Ministerio de Educación Pública. (1985). Serie Hacia la Luz. San José: Imprenta Nacional.

Murillo Rojas, Marielos. (1999). "La enseñanza del vocabulario en la educación general básica: propuesta metodológica”. Káñina, Revista de Artes y Letras de la Universidad de Costa Rica. XXIII (2).

Rojas, Marta. (2004). Desarrollo de la madurez léxica: Propuesta metodológica para sexto año. Informe de 
investigación. Vicerrectoría de Investigación. Universidad de Costa Rica.

. (2005). Desarrollo de la madurez léxica: Propuesta metodológica para cuarto año. Informe de investigación. Vicerrectoría de Investigación. Universidad de Costa Rica.

(2005). "Una responsabilidad escolar olvidada: el desarrollo del componente léxico". En Revista Educación de la Universidad de Costa Rica. 29 (1).

Rojas Porras, Marta y Ducca Durán, Isabel (1996). Español 6. Serie Hacia el siglo XXI. Ministerio de Educación Pública. Editorial Universidad de Costa Rica. San José.

Sánchez Corrales, Víctor. (1988). "Lexicografía del Español en Costa Rica, visión crítica". En: Revista de Filología y Lingüistica de la Universidad de Costa Rica. XIV (2).

. (1995). "Aportes de la lingüística a la enseñanza del español como lengua materna en Costa Rica: competencia sintáctica en niños preescolares". En: Revista Educación de la Universidad de Costa Rica. 19 (1).
(1998). "La lengua española en la educación costarricense, redefinición". En: Revista de Filología y Lingüistica de la Universidad de Costa Rica. XV (2).

- (1998). "Léxico básico de los escolares costarricenses: elementos diaintegrativos". En Revista Educación de la Universidad de Costa Rica. 22 (2).

Sánchez, Víctor y Murillo Rojas, Marielos. (1993). "Campos semánticos y disponibilidad léxica en preescolares". Revista Educación de la Universidad de Costa Rica. 27 (2).

(1993) "La enseñanza del español en la educación preescolar costarricense". En: Revista Educación de la Universidad de Costa Rica. 27 (1).

Universidad Nacional de Educación a Distancia (UNED). (2004). Madrid, España. Website: http://www.uned. es/biblioteca.

Zamora Elizondo, Hernán. (1942). Educación de la lengua materna. San José, Costa Rica: Editor Julián Zamora Robles. 